\title{
PENYULUHAN DENGAN MEDIA VIDEO MELALUI WHATSAPP GROUP TENTANG HEPATITIS B DAPAT MENINGKATKAN SKOR PENGETAHUAN IBU HAMIL
}

\author{
Ni Nyoman Lestari Yanti ${ }^{1}$, Ni Made Dwi Mahayati², Ni Wayan Armini ${ }^{3}$ \\ 1,2,3Poltekkes Kemenkes Denpasar Jurusan Kebidanan \\ *Korespondensi email lestariyanti789@gmail.com
}

\section{ABSTRACT EDUCATION WITH VIDEO MEDIA THROUGH WHATSAPP GROUP ABOUT HEPATITIS B CAN INCREASE KNOWLEDGE SCORES OF PREGNANT MOTHERS}

Background Hepatitis $B$ is a disease caused by the hepatitis $B$ virus, transmitted from mother to child transmission, information is needed to increase maternal knowledge about Hepatitis $B$, direct counseling was not carried out during the Covid pandemic, it was developed using video media through the WhatsApp group.

The Purpose was to determine the effect of video counseling through WhatsApp group about Hepatitis $B$ on the score of pregnant women.

Methods It is an experimental research, pretest-posttest control design method. The sample size was 54 people, with a control group of 27 people who were given a video that has been used at the public health, the experimental group with 27 people who were given a video developed by the researcher. Measurement of knowledge using the zoho form questionnaire.

The results of the Wilcoxon test have a significance of $0.000<005$, there are differences in knowledge before and after counseling, differences in knowledge between the intervention group and the control group with the Mann Withney test $0.004<0.04$.

The conclusion is that there is an effect of hepatitis $B$ counseling with video media via WhatsApp group on the knowledge of pregnant women in Sibangkaja Village.

Suggestion Health workers, public health in order to increase health promotion by developing media that is attractive and easy to understand by the community.

Keywords haptitis,pengetahuan,media

\section{ABSTRAK}

Latar Belakang Hepatitis B bisa menular dari ibu ke bayi sehingga diperlukan informasi untuk meningkatkan pengetahuan ibu tentang Hepatitis $B$, penyuluhan tatap muka tidak bisa dilakukan saat pandemi Covid.

Tujuan penelitian mengetahui peningkatan skor pengetahuan tentang hepatitis B pada ibu hamil setelah penyuluhan dengan media video melalui whatsapp group di Desa Sibang Kaja.

Metode Jenis penelitian eksperimen, metode pretest-posttest control design. Besar sampel 54 orang, dengan kelompok kontrol 27 responden diberikan video yang pernah dipakai di Puskesmas, kelompok eksperimen 27 responden diberikan video yang dikembangkan peneliti dengan materi lebih terfokus pada hepatitis pada kehamilan. Pengukuran pengetahuan dengan kuisioner dibuat pada zoho form.

Hasil uji Wilcoxon signifikansi $0,000<005$, terdapat perbedaan pengetahuan sebelum dan sesudah penyuluhan, perbedaan pengetahuan antara kelompok intervensi dan kelompok kontrol dengan uji Mann withney $0,004<0,04$.

Kesimpulan ada pengaruh penyuluhan hepatitis $B$ dengan media video melalui whatsapp group terhadap peningkatan skor pengetahuan ibu hamil di Desa Sibangkaja.

Saran Petugas kesehatan, Puskesmas agar meningkatkan promosi kesehatan dengan pengembangan media yang menarik dan mudah dimengerti masyarakat.

Kata Kunci : Hepatitis,Knowledge,media 


\section{JKM (Jurnal Kebidanan Malahayati),Vol 7,No.4.Oktober 2021, ISSN (Print) 2476-8944 ISSN (Online) 2579-762X, Hal 824-829}

\section{PENDAHULUAN}

Hepatitis merupakan masalah kesehatan masyarakat di dunia yang juga merupakan salah satu penyakit penyebab kematian perempuan di seluruh dunia. Hepatitis merupakan infeksi hepar yang paling sering mengenai wanita yang dapat menyebabkan defek koagulasi, kegagalan organ janin, peningkatan mortalitas maternal dan bayi baru lahir. Sampai saat ini telah diidentifikasi enam tipe virus hepatitis yaitu virus hepatitis $A, B, C, D, E$ dan G. Infeksi virus hepatitis yang paling sering menimbulkan komplikasi dalam kehamilan adalah virus hepatitis $B$ dan virus hepatitis $E$ (Lestari, 2015).

Virus Hepatitis B telah menginfeksi dua milyar orang di dunia, 240 juta di antaranya menjadi Hepatitis B kronik, sebanyak 1,5 juta penduduk meninggal dunia setiap tahun karena hepatitis. Indonesia merupakan negara dengan endemisitas hepatitis B tertinggi kedua di antara negara South East Asian Region (SEAR) setelah Myanmar (Gozali, 2020). Berdasarkan Sistem Informasi Hepatitis dan Penyakit Infeksi Saluran Pencernaan (SIHEPI) 2018-2019 di Indonesia jumlah ibu hamil yang diperiksa hepatitis B sebanyak 1. $643.204 \mathrm{di}$ 34 provinsi. Hasilnya, sebanyak 30.965 ibu hamil reaktif atau terinfeksi virus hepatitis $\mathrm{B}$ (Kemenkes, 2019). Tahun 2018 sebanyak $77,78 \%$ ibu hamil di Provinsi Bali telah melakukan deteksi dini hepatitis B dan sebanyak $1,44 \%$ ibu hamil dengan $\mathrm{HBsAg}$ reaktif (Kemenkes, 2019). Pada tahun 2018 sebanyak 6617 ibu hamil melakukan skrining dan ditemukan 134 orang $(2,02 \%)$ menunjukan hasil $\mathrm{HBsAg}$ rekatif di Kabupaten Badung (Dinkes Badung, 2019).

Penyebaran informasi tentang bahaya hepatitis B pada ibu hamil diperlukan untuk meningkatkan pengetahuan dan sikap juga perilaku ibu hamil untuk mau melakukan DDHB. Utami (2011) mengatakan bahwa pengetahuan berhubungan dengan praktik deteksi dini pada ibu hamil resiko tinggi. Syafriani (2017) menyimpulkan bahwa terdapat peningkatan pengetahuan mengenai deteksi dini kehamilan resiko tinggi setelah diberi penyuluhan kepada ibu hamil. Bidan memiliki kewenanagan untuk melakukan penyuluhan kesehatan sesuai dengan Permenkes Nomor 1464/Menkes.Per/X/2010 tenang izin dan penyelenggaraan praktik bidan disebutkan salah satu dari kewenanagan bidan adalah menjalankan program pemerintah dan melakukan penyuluhan dan konseling. Penyuluhan secara langsung dengan mengumpulkan ibu hamil disuatu tempat tidak mungkin dilaksanaan saat ini karena situasi pademi Covid-19. Pemerintah menghimbau untuk melakukan pembatasan aktifitas yang melibatkan banyak orang, apalagi ibu hamil merupakan kelompok rentan.

Media elektronik merupakan pilihan utama penyampaian informasi saat ini. Diperlukan pemilihan media yang tepat untuk digunakan, salah satunya adalah aplikasi WhatsApp Media sosial WhatsApp melalui beragam fitur yang disediakan dapat digunakan untuk kegiatan yang lebih bermanfaat, misalnya untuk pendidikan.

Desa Sibangkaja pada tahun 2020 memiliki ibu hamil pendatang yang paling banyak dibandingkan dengan desa lain di wilayah kerja Puskesmas Abiansemal III. Tingkat mobilitas penduduk pendatang lebih tingggi dari penduduk asli sehinga membutuhkan media untuk dapat memantau keadaan ibu hamil. Media yang digunakan saat ini di Desa Sibangkaja adalah aplikasi whatsapp, ibu hamil yang memiliki handphone android/IOS (90\%) dimasukan kedalam whatsapp group.

Penelitian ini bertujuan untuk mengetahui tentang pengaruh penyuluhan Hepatitis $B$ dengan media video melalui whatsapps group terhadap pengetahuan ibu hamil di Desa Sibangkaja tahun 2021.

\section{METODE PENELITIAN}

Dalam penelitian ini menggunakan metode penelitian eksperimen, nonrandomized control group pre test-post test design. purposive. Jenis data data primer, yang dikumpulkan dengan menggunakan kuisioner mengenai pengetahuan ibu tentang Hepatitis B pada kehamilan sebelum dan sesudah diberikan penyuluhan dengan video melalui whatsapp pada kelompok kontrol dan intervensi. Penelitan dilakukan tanggal 30 April-7 Mei 2021

Analisis data yang digunakan adalah univariate Untuk mengetahui normalitas data, digunakan uji Kolmogorov Smirnov dan didapatkan signifikansi $<0,05$ sehingga diasumsikan data berdistribusi tidak nomal. Analisis bivariate Dilakukan uji untuk mengetahui median perbedaan pengetahuan sebelum dan sesudah penyuluhan pada kelompok kontrol dan kelompok intervensi dengan distribusi data tidak normal menggunakan uji Wilcoxon dimana nilai $p$ value kelompok intervensi $0,000<0,05$ begitu juga pada kelompok kontrol dengan $p<0,05$.

Setelah diperoleh data post test dilakukan uji homogenitas dengan hasil sig 0,132>0,05 sehingga data adalah homogen. Selanjutnya dilakukan uji Mann Withney untuk mengetahui pengaruh penyuluhan dengan media video melalui 
Whatsapp group dengan membandingkan nilai post test antara kelompok kontrol dan intervensi dengan nilai asymp sig 0,004 <0,05.

\section{HASIL DAN PEMBAHASAN}

Karakteristik subjek penelitian

Gambaran karaktertistik responden yang diteliti dalam penelitian berdasarkan umur, pendidikan, pekerjaan, gravida yang disajkan dalam bentuk tabel dibawah ini.

Pada tabel 1 terlihat bahwa karakteristik responden berdasarkan umur pada kelompok intervensi sebagain besar pada kelompok umur reporduksi sehat yaitu 20 tahun sampai 35 tahun, sedangkan pada kelompok kontrol seluruh responden (100\%) berada pada kelompok umur 20 tahun sampai 35 tahun.

Berdasarkan karakteristik pekerjaan responden pada kelompok intervensi, sebgaian besar berada bekerja sebagai pegawai swasta $(44,4 \%)$, sedangkan pada kelompok kontrol sebagian besar ada ibu rumah tangga $(40,7 \%)$.

Tabel 1.

Gambaran Karakteristik Responden Kelompok Kontrol dan Kelompok Intervensi di Desa Sibangkaja

\begin{tabular}{|c|c|c|c|c|}
\hline \multirow{2}{*}{ Karakteristik } & \multicolumn{2}{|c|}{ Kelompok Kontrol } & \multicolumn{2}{|c|}{ Kelompok Intervens } \\
\hline & $f$ & $\%$ & $f$ & \\
\hline \multicolumn{5}{|l|}{ Usia } \\
\hline$<20$ th & 0 & 0 & 2 & 7,4 \\
\hline $20-35$ th & 27 & 100 & 20 & 74,1 \\
\hline$>35$ th & 0 & 0 & 5 & 18,5 \\
\hline \multicolumn{5}{|l|}{ Pekerjaan } \\
\hline IRT & 11 & 40,7 & 9 & 33,3 \\
\hline Wiraswasta & 9 & 33,3 & 3 & 11,1 \\
\hline Pegawai swasta & 6 & 22,3 & 12 & 44,5 \\
\hline PNS & 1 & 3,7 & 3 & 11,1 \\
\hline \multicolumn{5}{|l|}{ Pendidikan } \\
\hline SMA & 20 & 74,1 & 15 & 55,6 \\
\hline Perguruan Tinggi & 7 & 25,9 & 12 & 44,4 \\
\hline \multicolumn{5}{|l|}{ Gravida } \\
\hline Primigravida & 0 & 0 & 6 & 22,2 \\
\hline Multigravida & 18 & 66,7 & 14 & 51,9 \\
\hline Grandemultipara & 9 & 33,3 & 7 & 25,9 \\
\hline \multicolumn{5}{|c|}{ Informasi Hepatitis B pada Kehamilan } \\
\hline Nakes & 7 & 25,9 & 10 & 37,1 \\
\hline Internet & 10 & 37 & 11 & 40,7 \\
\hline Media elektronik (TV/Radio) & 4 & 14,9 & 2 & 7,4 \\
\hline Belum Pernah Mendengar & 6 & 22,2 & 4 & 14,8 \\
\hline Total & 27 & 100 & 27 & 100 \\
\hline
\end{tabular}

Berdasarkan karakteristik pendidikan baik pada kelompok intervensi $(55,6 \%)$ maupun kelompok kontrol $(74,1 \%)$ memiliki kesamaan yaitu sama-sama yang tertinggi berpendidikan SMA. Dilihat dari karakteristik kehamilan yang sekarang, kelompok intervensi $(51,9 \%)$ dan kelompok kontrol $(66,7 \%)$ sebagian besar merupakan mutigravida, tidak ada primigravida pada kelompok kontrol. Berdasarkan informasi yang pernah didapat sebelumnya tentang hepatitis B pada kehamilan, pada kelompok intervensi dan kontrol sebagain besar responden sama- sama mendapatkan informasi yang bersumber dari internet. Pada kelompok intervensi ada 4 orang $(14,7 \%)$ dan pada kelompok kontrol ada 6 orang $(22,2 \%)$ yang belum pernah mendengar informasi tentang hepatitis $B$ pada kehamilan.

Hasil pengamatan terhadap subjek penelitian berdasarkan variabel penelitian

Hasil pengamatan terhadap subjek penelitian digambarkan melalui uji normalitas data pada kelompok kontrol sebelum dan sesudah penyuluhan dan kelompok intervensi sebelum dan sesudah penyuluhan signifikansi hasil prestes dan post tes pada kelompok kontrol maupun kelompok intervensi $<0,05$, maka dapat disimpulkan bahwa data 
berdistribusi tidak normal sesuai pada tabel di bawah ini.

Tabel 2.

Uji Normalitas Data Tingkat Pengetahun Tentang Hepatitis B pada Kelompok Intervensi dan Kelompok Kontrol Di Desa Sibang Kaja Tahun 2021

\begin{tabular}{lccc}
\hline \multicolumn{1}{c}{ Tingkat Pengetahuan } & Statistik & n & sig \\
\hline Pre Tes Kelompok Kontrol & 0,189 & 27 & $0.014^{*}$ \\
Post Tes Kelompok Kontrol & 0,190 & 27 & $0.013^{*}$ \\
\hline Pre Tes Kelompok Intervensi & 0,198 & 27 & $0,008^{*}$ \\
Post Tes Kelompok Intervensi & 0,302 & 27 & $0.000^{*}$ \\
\hline
\end{tabular}

*uji kolmogorov-smirnov

Karena data berdistribusi tidak normal maka dilanjutkan uji dengan uji Wilcoxon untuk mengetahui perbedaan pengetahuan sebelum dan setelah penyuluhan pada kelompok kontrol dan intervensi, dan uji Mann Withney untuk mengetahui pengaruh penyuluhan antara kelompok kontrol dan perlakuan.
Tingkat pengetahuan sebelum diberikan penyuluhan

Distribusi tingkat pengetahuan responden sebelum dilakukan penyuluhan dapat dilihat pada tabel di bawah ini.

Tabel 3.

Tingkat Pengetahuan Tentang Hepatitis B Sebelum Penyuluhan Pada Kelompok Kontrol Dan Kelompok Intervensi Di Desa Sibangkaja Tahun 2021

\begin{tabular}{lcccc}
\hline \multirow{2}{*}{ Pengetahuan sebelum } & & \multicolumn{2}{c}{ Tingkat Pencapaian } & \multirow{2}{*}{ Median } \\
\cline { 3 - 4 } & $\mathbf{n}$ & Minimum & Maksimum & \\
\hline Kelompok Kontrol & 27 & 55 & 90 & 73 \\
Kelompok Intervensi & 27 & 55 & 73 & 64 \\
\hline
\end{tabular}

Pada tabel 5 dijelaskan nilai median kelompok kontrol 73 , nilai minimum 55 dan maksimum 90. Pada kelompok intervensi median 64, minum 55 dan maksimum 64.

Tingkat pengetahuan setelah diberikan penyuluhan

Distribusi tingkat pengetahuan responden setelah diberikan penyuluhan menggunakan media video melalui WhatsApp group dapat dilihat pada tabel dibawah ini. pada kelompok kontrol yaitu nilai median 73 dengan nilai minimum 63 dan nilai maksimum 91 sedangkan pada kelompok intervensi 82 dengan nilai minimum 72 dan maksimum 91 yang dapat dilihat pada tabel di bawah ini.

Pada tabel 6 dijelaskan nilai median pada kelompok kontrol 73 dengan nilai minimum 63 dan nilai maksimum 91 , sedangkan pada kelompok intervensi 82 dengan nilai minimum 72 dan maksimum 91 .

Tabel 4.

Tingkat Pengetahuan Tentang Hepatitis B Pada Kelompok Kontrol Dan Kelompok Intervensi Setelah Penyuluhan Di Desa Sibangkaja Tahun 2021

\begin{tabular}{ccccc}
\hline \multirow{2}{*}{ Pengetahuan sesudah } & & \multicolumn{2}{c}{ Tingkat Pencapaian } & \multirow{2}{*}{ Median } \\
\cline { 3 - 4 } & $\mathbf{n}$ & Minimum & Maksimum & \\
\hline Kelompok Kontrol & 27 & 63 & 91 & 73 \\
Kelompok Intervensi & 27 & 72 & 91 & 82 \\
\hline
\end{tabular}

Perbedann pengetahuan sebelum dan setelah penyuluhan menggunakan media video melalui WhatsApp Group terhadap pengetahuan ibu hamil tentang hepatitis B pada kelompok kontrol dan intervensi

Hasil penelitian mengenai perbedaan pengetahuan sebelum dan setelah penyuluhan 
pada kelompok kontrol dan intervensi dengan menggunakan uji Wilcoxon dapat dilihat dari tabel di bawah ini.yaitu nilai pada kelompok kontrol dengan $p<0,05$ dengan interpretasi terdapat pengaruh penyuluhan menggunakan media video melalui WhatsApp group terhadap pengetahuan ibu tentang hepatitis B pada kelompok kontrol. Hal yang sama juga terlihat pada kelompok intervensi yaitu $p$ value kelompok intervensi $0,000<0,05$ dengan intreprestasi bahwa ada pengaruh penyuluhan dengan media video melalui WhatsApp terhadap pengetahuan ibu hamil tentang hepatitis $B$ yang dapat dilihat pada tabel di bawah ini.

Tabel 5.

Pengaruh Penyuluhan Hepatitis B Pada Kelompok Kontrol dan Intervensi dengan Media Video Melalui Whatsapps Group Terhadap Pengetahuan Ibu hamil di Desa Sibangkaja

\begin{tabular}{lccc}
\hline \multicolumn{1}{c}{ Tingkat Pengetahuan } & $\mathbf{n}$ & $\mathbf{z}$ & $\mathbf{p}$ value \\
\hline Hasil pre tes - post tes kelompok kontrol & 27 & $-3,794^{b}$ & 0,000 \\
Hasil pre tes - post tes kelompok intervensi & 27 & $-4,584^{b}$ & 0,000 \\
\hline
\end{tabular}

Keterangan : Uji Wilcoxon

Dari tabel 7 diketahui nilai pada kelompok kontrol dengan $p$ value $0,000<0,05$ dan pada kelompok intervensi yaitu $p$ value $0,000<0,05$ dengan intreprestasi ada pengaruh penyuluhan dengan media video melalui WhatsApp terhadap pengetahuan ibu hamil tentang Hepatitis $B$.
Pengaruh penyuluhan dengan media video melalui whatsapps group tentang hepatitis B terhadap pengetahuan ibu hamil di Desa Sibangkaja

Untuk mengetahui perbedaan pengaruh penyuluhan dengan media video melalui WhatsApp Group antara kelompok kontrol dan kelompok intervensi digunakan uji Mann Whitney, dapat dilihat pada tabel di bawah ini.

Tabel 6

Perbedaan pengaruh penyuluhan pada kelompok intervensi dan kelompok kontrol tentang hepatitis $B$ dengan media video melalui whatsapps group terhadap pengetahuan ibu hamil di Desa Sibangkaja

\begin{tabular}{llcc}
\hline & $\mathbf{n}$ & Median (Minimum-maksimum) & $\boldsymbol{p}$ \\
\hline Nilai kelompok kontrol & 27 & $81(63-91)$ & 0,004 \\
Nilai kelompok intervensi & 27 & $82(72-91)$ & 0,004 \\
\hline
\end{tabular}

Keterangan : Uji Mann Whitney

Dari uji Mann Whitney didapatkan bahwa berdasarkan output statistik diketahui nilai asymp signifikansi sebesar $0,004<0,05$. Maka dapat disimpulkan bahwa hipotesis diterima, dan ada perbedaan hasil antara kelompok kontrol dan kelompok intervensi. Karena ada perbedaan yang signifikan maka dapat dikatakan bahwa ada pengaruh penyuluhan dengan media video melalui whatsapps group dengan peningkatan pengetahuan ibu hamil tentang Hepatitis B pada kehamilan di Desa Sibangkaja.

Hasil penelitian ini sejalan dengan hasil penelitian Asututi (2020) menyimpulkan ada pengaruh sikap ibu hamil trimester III sebelum dan setelah diberikan penyuluhan berbasis video whatsapp tentang persalinan di wilayah kerja Puskesmas Klabang Kabupaten Bondowoso.
Media merupakan salah satu faktor penentu keberhasilan pembelajaran. Melalui media proses pembelajaran bisa lebih menarik dan menyenangkan (joyfull learning). Dengan menggunakan media berteknologi, dapat membantu dalam peningkatan pengetahuan ibu hamil tentang hepatitis B pada kehamilan. Aspek penting lainnya adalah membantu memperjelas pesan pembelajaran. Disinilah peran media, sebagai alat bantu memperjelas pesan pembelajaran (Hamtiah, 2012).

\section{SIMPULAN}

Skor pengetahuan ibu hamil sebelum diberikan penyuluhan dengan media video melalui whatsapp group tentang hepatitis B pada masa kehamilan di Desa Sibangkaja yaitu nilai median 


\section{JKM (Jurnal Kebidanan Malahayati),Vol 7,No.4.Oktober 2021, \\ ISSN (Print) 2476-8944 ISSN (Online) 2579-762X, Hal 824-829}

kelompok intervensi 64 sedangkan kelompok kontrol nilia median 73

Skor pengetahuan ibu hamil setelah diberikan penyuluhan dengan media video melalui whatsapp group tentang hepatitis B pada masa kehamilan di Desa Sibangkaja yaitu nilai median kelompok intervensi 82 sedangkan kelompok kontrol nilai median 81. Penyuluhan dengan video melalui media whatsap berperngaruh terhadap peningkatan skor pengetahuan ibu hamil tentang hepatitis pad kehamilan. Ada pengaruh penyuluhan hepatitis $B$ dengan media video yang dikembangkan peneliti melalui whatsapps group terhadap peningkatan skor pengetahuan ibu hamil tentang hepatitis B selama kehamilan di Desa Sibangkaja.

\section{SARAN}

Petugas kesehatan, Puskesmas agar meningkatkan promosi kesehatan dengan pengembangan media yang menarik dan mudah dimengerti masyarakat.

\section{DAFTAR PUSTAKA}

Astuti. 2020. Manfaat Penyuluhan Dengan Media Whatsapp Terhadap Pengetahuan Ibu Hamil Trimester I Tentang Emesis Gravidarum, Sripsi, Politeknik Kesehatan Kemenkes Denpasar

Budiman, Riyanto A. 2013. Kapita Selekta Kuisioner Pengetahuan Dan Sikap Dalam Penelitian Kesehatan. Jakarta : Salemba Medika

Dinas Kesehatan Kabupaten Badung. 2019. Siapa Yang Berperan Dalam Penanggulangan Hepatitis B, Pemerintah Atau Masyarakat, Https:/Www.Dikes.Badungkab.Go.Id/Artikel/ Read/660/Siapa-Yang-Berperan-DalamPenanggulangan-Hepatitis-B--PemerintahAtau-Masyarakat?.Html, Diakses Pada 4 Peburuari

Gozali AP. 2020. Diagnosis, Tatalaksana, dan Pencegahan Hepatitis B dalam Kehamilan.CDK-286, Vol. 47 no. 5
Hamtiah, S., Dwijatmiko, S., \& Satmoko, S. 2012 Efektivitas Media Audio Visual (Video) Terhadap Tingkat Pengetahuan Petani Ternak Sapi Perah Tentang Kualitas Susu.Universitas Diponegoro, Semarang,Animal Agriculture Journal,Vol 1 No 2

Kementerian Kesehatan R I . 2017. Pedoman Eliminasi Penularan HIV, Sifilis, Dan Hepatitis dari lbu Ke Anak, Direktorat Jendral Pencegahan Dan Pengendalian Penyakit. Jakarta.

Kementerian Kesehatan R.1. 2019. Profil Kesehatan Indonesia. Kemetrian Kesehatan R.I. Jakarta

Lestari RI. 2015. Pengaruh Hepatitis Terhadap Kehamilan, J Agromed Unila Volume 2 Nomor 2 Mei 2015

Larasati W. 2013. Efektivitas Pemanfaatan Aplikasi Whatsapp Sebagai Sarana Pembelajaran Para Mahasiswa Fakultas IImu Sosial dan Humaniora Uin Sunan Kalijaga Yogyakarta.

Utami S. 2011. Faktor-Faktor Yang Berhubungan Dengan Praktik Deteksi Dini Ibu Hamil Risiko Tinggi Oleh Bidan Di Kabupaten Banjarnegara Tahun 2011 Skripsi.; 2011. Http://Lib.Ui.Ac.Id/File?File=Digital/201611/20439558- S-Pdf-Sri Budi Utami.Pdf.

Syafriani dan Indrawati. 2017. Pengaruh Metode Penyuluhan Deteksi Dini Kehamilan Risiko Tinggi Terhadap Pengetahuan Ibu Hamil Pada Kelas Prenatal Di Puskesmas Bangkinang Kota Kabupaten Kampar, Jurnal Doppler Universitas Pahlawan Tuanku Tambusai, Vol 1 No 2 Tahun 2017

Zulfian, Octa R, Sapitia A. 2018. Hubungan Tingkat Pengetahuan lbu Hamil Dengan Kejadian Hepatitis B Di Puskesmas Beringin Kecamatan Lubai Kota Palembang, Jurnal Ilmu Kedokteran Dan Kesehatan, Volume 5, Nomor 3 